\title{
STUDI PERENCANAAN PEMELIHARAAN PERKERASAN JALAN MENGGUNAKAN TEKNOLOGI DAUR ULANG
}

\author{
Melchior Bria, Anastasia H. Muda, Lodofikus Dumin, Abia E. Mata, SST \\ Jurusan Teknik Sipil, Politeknik Negeri Kupang \\ Email : melchibria@yahoo.co.id
}

\begin{abstract}
ABSTRAK
Ruas Jalan Kupang - Tablolong, Lakafehan - Kolam Susu, Kefamenanu - Wini dan Soe - Kapan (Fatumnasi) merupakan ruas jalan menuju lokasi wisata andalan di Timor. Pada keempat ruas jalan tersebut telah dilakukan pemeliharaan dengan cara pelapisan ulang, akan tetapi t etap mengalami kerusakan. Sehingga perlu diobesrvasi nilai kondisi perkerasan jalan dan potensi penggunaan teknologi daur ulang perkerasan aspal. Hasil penelitian menunjukkan nilai kondisi masing-masing perkerasan jalan antara $2-8$ yang menunjukkan mayoritas perlu dilakukan program peningkatan jalan. Pengujian terhadap material eksisiting memberikan hasil jenis campuran aspal yang dipakai adalah Asphalt Concrete (AC., Rata-rata persen kadar aspal dalam campuran antara 6\% - 7,8\%,. Selanjutnya, menggunakan AHSP 2013 diperoleh penghematan biaya per ton pekerjaan perkerasan Jalan AC pada ruas-ruas jalan tersebut adalah sebesar $13-19 \%$.
\end{abstract}

Kata kunci: pemeliharaan, daur ulang, perkerasan, biaya

\section{Pendahuluan}

Ruas jalan dengan status jalan provinsi di wilayah Timor, beberapa diantaranya sebagai akses utama menuju kawasan wisata andalan di Timor antara lain Ruas Jalan Kupang - Tablolong, Lakafehan Kolam Susu, Kefamenanu - Wini dan Soe Kapan (Fatumnasi). Namun demikian, sebagaian besar ruas jalan tersebut mengalami kerusakan. Upaya yang selama ini dilakukan adalah dengan melakukan pelapisan ulang (overlay). Setiap ada kerusakan jalan baik rusak ringan maupun berat metode yang digunakan adalah pelapisan ulang (Bria,2015).

Penggunaan metode ini bukan tanpa masalah. Seiring dengan penggunaannya, ternyata overlay memiliki kelemahan, antara lain over design, biaya tinggi, dan menyebabkan masalah lingkungan (Aly, 2008). Dengan demikian perlu dipertimbangkan penerapan metode penanganan perkerasan jalan yang lebih baik. Salah satunya dengan menerapkan prinsip greenroads, yaitu menggunakan material yang didaur ulang dengan atau tanpa bahan tambah yang dapat mendukung pembangunan konstruksi jalan berkelanjutan.

Untuk itu, sebelumnya perlu dilakukan suatu studi penilaian terhadap kondisi perkerasan jalan, bagaimana kondisi ruas jalan, baik, rusak ringan atau rusak berat. Dari kondisi perkerasan jalan ini, selanjutnya dapat disusun beberapa kriteria yang akan digunakan untuk membuat model pengambilan keputusan.

\section{Tinjauan Pustaka}

Lapisan perkerasan jalan adalah lapisan permukaan yang keras diletakan pada formasi tanah setelah selasainya pekerjaan tanah atau struktur yang memisahkan ban kendaraan dengan lapisan pondasi yang berada di bawahnya (Hardyatmo, 2007). Lapisan ini terletak di atas tanah dasar yang telah mengalami pemadatan. Lapisan perkerasan berfungsi untuk menerima beban langsung dari kendaraan yang melewatinya untuk kemudian didistribusikan ke badan jalan, memberikan permukaan rata/halus bagi pengendara, dan melindungi tanah dari pengaruh buruk cuaca.

Sedangkan konstruksi perkerasan lentur (flexible pavement), yaitu perkerasan yang menggunakan aspal sebagai bahan pengikat. Disebut "lentur" karena konstruksi ini mengijinkan terjadinya deformasi vertikal akibat beban lalu lintas dari permukaan sampai ke tanah dasar. Salah satujenis 
perkerasan lentur adalah HRS, Porous Asphalt (PA) serta Asphalt Concrete (AC). Perkerasan lentur umumnya terdiri dari tiga lapisan utama yaitu Lapis Permukaan (surface course), lapisan pondasi (base course) dan lapisan pondasi bawah (sub base course).

\begin{tabular}{|l|l|}
\hline Lapis aus \\
\hline \hline Lapis permukaan dasar \\
\hline
\end{tabular}

Lapis pondasi jalan

Lapis pondasi bawah

Lapisan menutup

Lapisan tanah dasar

Sumber : Wignall, 2003

Gambar 1. Struktur Lapisan Jalan

Dalam pembangunan jalan, pemasangan lapisan permukaan umumnya berbiaya tinggi. Hal ini karena fungsi dari lapisan permukaan adalah memberikan keamanan dan kenyamanan bagi pengendara dan harus memenuhi syarat kekesatan atau tahan terhadap gelinciran, menahan beban kendaraan dan deformasi permanen, dan mencegah masuknya air ke dalam struktur perkerasan. Sehingga campuran yang digunakan untuk lapisan permukaan harus memiliki sifat stabilitas, kelenturan, awet, tahan terhadap gelincir, kedap air, mudah dikerjakan, dan tahan terhadap kelelehan (Hardyatmo, 2007; Wignall, 2003).

Dengan demikian, mengingat biaya tinggi dan penggunaan bahan alam yang cukup signifikan maka penggunaan teknik daur ulang atau penggunaan kembali material jalan asli dengan konsep daur ulang (recycling pavement asphalt (RAP)), yaitu penggunaan kembali konstruksi perkerasan lama (eksisting), baik dengan ataupun tanpa tambahan bahan baru untuk keperluan pemeliharaan, perbaikan maupun peningkatan konstruksi perkerasan jalan, adalah pilihan yang tepat. Teknologi ini terdapat 7 jenis metode daur ulang konstruksi perkerasan jalan, yaitu : (1) hot mix recycle; (2) cold mix recycle; (3) surface recycle; (4) reconstruct with all new material; (5) patch and thick overlay; (6) patch and thin overlay; (7) patch pada rutin maintanence (Ally, 2008).

Pada dasarnya Teknologi Pavement Recycling adalah teknik untuk merehabilitasi/merekonstruksi dan/atau meningkatkan perkerasan jalan dengan mengolah kembali (daur ulang) material perkerasan lama menjadi perkerasan baru yang lebih kuat. Konsep ini dikenal dengan istilah New Roads from Old. Pada dasarnya, hakekat dari pavement recycling adalah mengoptimalkan penggunaan material jalan yang sudah ada di lokasi pekerjaan.

Semua proses recycling terdiri dari 4 (empat) kategori adalah sebagai berikut (Nicholls, 1998):

1. Hot Recycling: adalah proses daur ulang panas dimana reclaimed dikombinasikan dengan agregat dan aspal baru apabila diperlukan, kemudian dicampur dan dipanaskan dengan temperatur tertentu untuk memproduksi HMA.

2. Cold Recycling adalah proses daur ulang tanpa pemanasan tetapi dilakukan sesuai dengan suhu lingkungan atau suhu sekitarnya, kemudian dihampar dan dipadatkan serta difungsikan sebagai lapisan di bawah lapis permukaan.

3. In-Situ Recycling: merupakan proses daur ulang yang dilakukan langsung di lokasi dengan memanfaatkan mesin recycling khusus, yang perangkat utamanya adalah millingdrum yang dilengkapi dengan gigigigi penghancur. Millingdrum ini dapat berputar dan melakukan proses penghancuran dan pencampuran material bekas perkerasan lama dengan material baru atau bahan pengikat jika diperlukan, sampai kedalaman tertentu.

In-Plant Recycling: dilakukan dengan memanfaatkan mesin penghancur perkerasan jalan (milling) kemudian dibawa ke plant dengan dump tuck, diproses di plant dan dibawa kembali ke lapangan untuk ditebarkan dan dipadatkan.

Pada akhir tahun 1991 atau awal tahun 1992, diadakan serangkaian penelitian guna menetapkan spesifikasi penggunaan RAP untuk perkerasan jalan dengan lalu lintas berat. Campuran aspal yang berisi $10 \%$ RAP bisa digunakan untuk lapis permukaan tanpa pengujian. Sedangkan campuran aspal yang menggunakan lebih besar $10 \%$ RAP 
harus dilakukan pengujian terlebih dahulu (Nicholls, 2008).

Ada tiga jenis bahan yang digunakan pada daur ulang campuran panas, yaitu bahan garukan perkerasan lama, agregat dan aspal baru.

Sedangkan Lapis perkerasan harus memenuhi karakteristik tertentu sehingga didapat lapis perkerasan yang kuat, aman, dan nyaman untuk dilewati kendaraan. Khususnya untuk perkerasan lentur, karakteristik perkerasannya tidak lepas dari sifat-sifat bahan penyusunya, yaitu sifat-sifat dari aspal dan agregat. Adapun karakteristik perkerasan meliputi : Stabilitas; Kelelahan (flow); Durabilitas; Tahanan Geser (Skid Resistance); Fleksibilitas (Kelenturan); Porositas ; Permeabilitas; Kuat tarik; Kuat Tekan.

Pengujian campuran beraspal dilakukan melalui serangkaian pemeriksaan/pengujian sebagai berikut (Puslitbang Jalan dan Jembatan, 2006), yaitu :

\section{A. Pemeriksaan Volumetrik Test}

a. Densitas

$$
D=\frac{W d r y}{(W s-W w)}
$$

b. Spesific Grafity Campuran

$$
\text { SGmix }=\frac{100}{\frac{\% W a k}{S G a k}+\frac{\% W a h}{S G a h}+\frac{\% W f}{S G f}+\frac{\% W b}{S G b}}
$$

c. Porositas

$$
P=\left[1-\frac{D}{S G m i x}\right] x 100
$$

\section{B. Marshall Test}

Uji Marshall dilakukan untuk menentukan stabilitas, flow dan Marshall Quotient. Selanjutnya hasil tersebut digunakan untuk menentukan kadar aspal optimum.

a. Stabilitas

$$
\mathrm{S}=\mathrm{q} \times \mathrm{k} \times \mathrm{H} \times 0,454
$$

b. Flow

\section{c. Marshall Quotient}

$$
M Q=\frac{S}{f}
$$

C. Uji Kuat Tarik Tidak Langsung (Inderect Tensile Strength Test)

Inderect Tensile Strength Test adalah metode pengujian gaya tarik secara tidak langsung untuk mengetahui karakter tensile dari campuran perkerasan.

$$
I T S=\frac{2 x \bar{P}}{\pi(d h)}
$$

\section{Uji Kuat Tekan Bebas (Unconfined} Compressive Strength Test)

Kuat tekan bebas adalah kemampuan lapisan perkerasan untuk menahan beban yang ada secara vertikal yang dinyatakan dalam $\mathrm{kg}$ atau $\mathrm{lb}$.

$U C S=\frac{\bar{P}}{A}$

\section{E. Permeability Test}

$k=\frac{V x L x \gamma}{A x P x T}$

\section{Metodologi}

Penelitian ini dikerjakan dalam beberapa tahapan yaitu, pertama: menentukan nilai kondisi ruas jalan, kedua: membuat model pengambilan keputusan dan ketiga: analisa penggunaan RAP.

Adapun ruas jalan yang diidentifikasi adalah ruas jalan yang menuju lokasi wisata andalan di Pulau Timor, yaitu ruas jalan kupang Tablolong (KM 18 - KM 23), ruas jalan Soe - Kapan (Fatumnasi). Ruas jalan Kefamenanu - Wini (Teluk Bastian), dan Ruas Jalan Lakafehan Kolam Susu.

Penentuan nilai kondisi menggunakan metode RCI, yaitu suatu cara melakukan penilaian kondisi perkerasan jalan dengan melakukan pengamatan secara visual untuk mengidentifikasi kerusakan, mengukur dimensi terhadap 
kerusakan, dan melakukan penilaian berdasarkan dengan RDS 70 (1989) dimana kondisi jalan dinyatakan dalam kondisi Baik, Sedang, Rusak Ringan dan Rusak Berat seperti Tabel 1. Sedangkan model pengambilan keputusan menggunakan metode Analytical Hirerchy Process (AHP).

Tabel 1

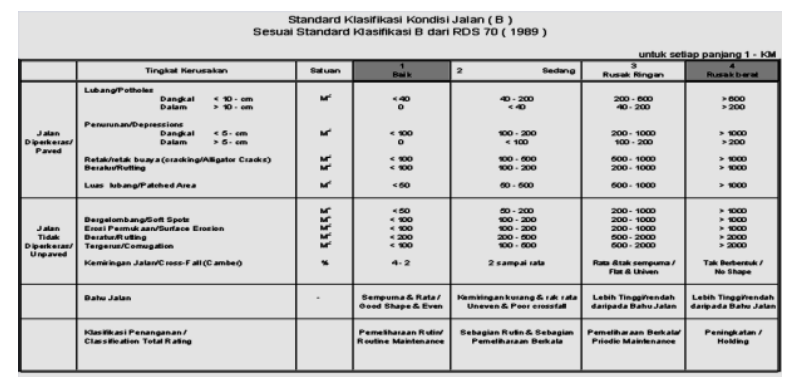

Sumber : Soemino, dkk (2005

Analisa penggunaan RAP dilakukan dengan cara pengambilan material eksisiting dengan sampel pada Kilometer yang mengalami kerusakan cukup signifikan. Pengujian Laboratorium untuk RAP dilakukan di Lab. Pengujian Bahan Jurusan Teknik Sipil Politeknik Negeri Kupang. Bahanbahan yang digunakan dalam penelitian ini adalah (1) Reclaimed Asphalt Pavement (2) Aspal dan agregat baru. Selanjutnya dilakukan uji Ekstrasi untuk mengetahui kadar aspal perkerasan lama dan membuat mix dengan bahan tambah atau tanpa bahan tambah dan diuji dengan Uji Marshall. Analisa ekonomi penggunaan RAP, dilakukan berdasarkan Analisa Harga Satuan Pekerjaan (AHSP) 2013.

\section{Hasil Dan Pembahasan}

Identifikasi kondisi ruas jalan dilakukan dengan cara observasi atas perkerasan jalan dan selanjutnya menentukan kerusakan jalan, mengukur dimensi kerusakan dan melakukan pencatatan atas hasil observasi. Dari identifikasi diperoleh hasil jenis kerusakan dan volume kerusakan jalan dalam meter persegi.
Tabel 2 Jenis dan Volume Kerusakan Ruas Jalan

\begin{tabular}{|c|c|c|c|c|c|c|c|c|c|}
\hline \multirow[b]{2}{*}{ No } & \multirow[b]{2}{*}{ RUAS JALAN } & \multicolumn{8}{|c|}{ JENIS DAN VOLUME KERUSAKAN } \\
\hline & & A & B & C & D & E & $\mathrm{F}$ & G & $\mathrm{H}$ \\
\hline 1 & Kupang - Tablolong & 20,75 & 201,25 & 4750,00 & & & & & \\
\hline 2 & Lakafehan - Kolam Susuk & 10,30 & & & & & & & \\
\hline 3 & Maubesi (Kefamenanu) - Wimi & & & 7043,75 & 1312,50 & & & & 360,00 \\
\hline & $\begin{array}{l}\text { Soe - Kapan - Fatumnasi (Cagar } \\
\text { Alam Mutis) }\end{array}$ & & & 1875,00 & 13460,00 & 26400,00 & & & \\
\hline \multicolumn{10}{|c|}{ Keterangan: } \\
\hline A & Lubang & & & & & & & & \\
\hline B & Amblas & & & & & & & & \\
\hline C & Retak Memanjang & & & & & & & & \\
\hline D & Kerusakan tepi & & & & & & & & \\
\hline E & Terkelupas/Pelepasan Butiran & & & & & & & & \\
\hline $\mathrm{F}$ & Gelombang & & & & & & & & \\
\hline G & Aus/Wearing & & & & & & & & \\
\hline $\mathrm{H}$ & Kegemukan/Bleeding & & & & & & & & \\
\hline
\end{tabular}

Ruas jalan Kupang - Tablolong, dalam penelitian ini dibagi dalam dua ruas yaitu mulai STA $08+$ 0,00 - STA $18+0,00$ dan STA 0,00 - STA 2,00 $+0,00$. Sebagaimana teridentifikasi bahwa pada STA pertama, kondisi jalan pada STA tertentu mengalami kerusakan, antara lain retak memanjang, umumnya sangat terlihat mulai STA $8+0,00-$ STA $9+500$, Lubang dan amblas pada STA $11+0,00-$ STA $12+0,00$. Secara keseluruhan, ruas jalan ini dalam kondisi sedang dengan kemantapan jalan masih dalam kategori mantap dengan nilai RCI 7 , sehingga pemeliharaannya cukup dengan perawatan (pemeliharaan rutin), yaitu memperbaiki kerusakan-kerusakan yang terjadi pada ruas jalan dengan kondisi pelayanan mantap. Pada ruas jalan masuk Pantai Tablolong dari Gapura kondisi jalan rusak berat, ditandai dengan pelepasan butiran lapisan permukaan jalan kurang lebih sekitar 500 meter dan selanjutnya hingga mencapai pantai, lapisan permukaan jalan tidak terlihat sama sekali. Dengan nilai RCI 2, maka direkomendasikan jenis pemeliharaannya adalah peningkatan agar ruas jalan tersebut dapat melayani lalu lintas dengan mantap.

Untuk ruas jalan Lakafehan (Berluli) - Kolam Susuk, kondisi jalan mantap dengan nilai RCI 8 dan tidak terlihat adanya kerusakan yang berarti akan tetapi terdapat sedikit gelombang, pada tepi jalan terdapat sedikit lubang (disebabkan penurunan timbunan pada tepi jalan dan sedikit 
aus pada permukaan jalan di bagian tepi jalan. Aus ini lebih disebabkan oleh beban kendaraan yang melewatinya.

Selanjutnya, ruas jalan Maubesi di Kefamenanu menuju Wini, Kabupaten TTU, kondisinya cukup baik dengan kemantapan jalan masih mantap (Nilai RCI 7). Kerusakan terjadi pada STA $20+$ 500 - STA $3+0,00$ sebagaimana yang teridentifikasi, berupa retak memanjang, kerusakan tepi (amblas pada tepi) dan kegemukan (bleeding). Namun jika ditinjau secara keseluruhan sekitar 40000 meter panjang jalan, maka kondisinya cukup baik. Sehingga kategorinya masuk pada pemeliharaan rutin berupa perawatan untuk menjaga jalan tetap melayani lalu lintas dengan baik.

Sedangkan ruas Jalan Soe - Kapan - Cagar Alam Gunung Mutis, pada saat pengamatan dibagi dalam dua seksi yaitu Soe - Kapan dan Kapan Fatumnasi yang merupakan akses utama menuju Cagar Alam Gunung Mutis. Untuk ruas Soe Kapan kondisinya tidak mantap dan mengalami rusak ringan dengan nilai RCI 6. Sedangkan ruas jalan Kapan - Fatumnasi, kondisinya sangat memprihatinkan, mengalami kerusakan yang cukup berat, berlubang, pelepasan butiran, hampir pada semua permukaan jalan. Indeks kondisi jalannya adalah 3 sehingga direkomendasikan untuk melakukan peningkatan.
Tabel 3. Nilai RCI, Kondisi Jalan, Tingkat

Kemantapan, Potensi dan Rekomendasi Jenis Pemeliharaan

\begin{tabular}{|c|c|c|c|c|c|c|}
\hline No & RUAS JALAN & $\mathrm{RCI}$ & KONDISI JALAN & $\begin{array}{l}\text { KEMANTAPAN } \\
\text { JALAN }\end{array}$ & $\begin{array}{l}\text { POTENSI DAUR } \\
\text { ULANG } \\
\text { PERKERASAY }\end{array}$ & $\begin{array}{l}\text { REKOVENDASI } \\
\text { JENIS } \\
\text { PENELIHARAAN }\end{array}$ \\
\hline 1 & Kupang - Tablolong & & & & & \\
\hline a & Ruas I (Batulesa - Tablolong) & 7.00 & Sedang & Mantap & HMA & Rehabilitasi \\
\hline$b$ & Ruas II (Gapura - Pantai Tablolong & 2.00 & Rusak Berat & Tidak Mantap & Lapen & Pembangunan baru \\
\hline 2 & $\begin{array}{l}\text { Lakafehan - Kolam Susuk - Teluk } \\
\text { Gurita }\end{array}$ & & & & & \\
\hline a & Ruas Lakalehan - Kolam Susuk & 8.00 & Baik & Mantap & HMA & Perawatan \\
\hline$b$ & Ruas Kolam Susuk Teluk Gurita & 3.00 & Rusak Berat & Tidak Mantap & Lapen & Peningkatan \\
\hline 3 & Maubesi (Kefamenanu) - Wini & 7.00 & Sedang & Mantap & HMA & Rehabilitasi \\
\hline 4 & $\begin{array}{l}\text { Soe - Kapan - Fatumnasi (Cagar } \\
\text { Alam Mutis) } \\
\end{array}$ & & & & & \\
\hline & Ruas Soe Kapan & 6.00 & Rusak Ringan & Tidak Mantap & HMA & Peningkatan \\
\hline & Ruas Kapan - Fatumnasi & 2.00 & Rusak Berat & Tidak Mantap & Lapen & Peningkatan \\
\hline
\end{tabular}

Sumber : Hasil analisa, 2015

Selanjutnya menggunakan metode AHP, dapat ditentukan jenis pemeliharaan yang paling prioritas untuk dikerjakan. Langkah pertama adalah dengan membuat model pengambilan keputusan dengan 3 level, yaitu level tujuan, kriteria dan level alternatif.

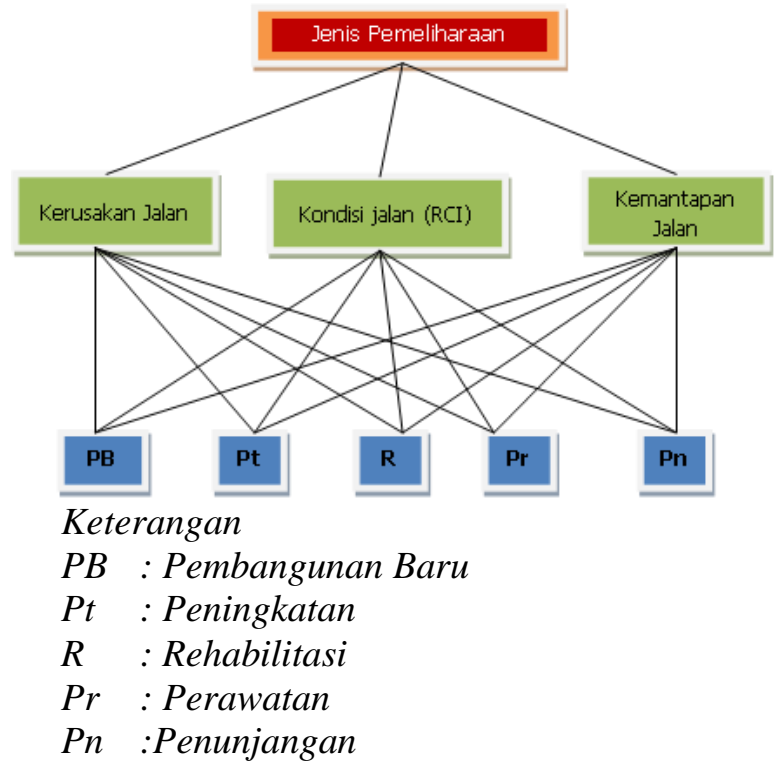

Model tersebut di atas kemudian diajukan kepada responden untuk melakukan penilaian terhadap Kriteria dan jenis pemeliharaannya. Dari hasil sintesa terakhir, dapat disimpulkan bahwa untuk jenis pemeliharaan yang paling penting berdasarkan kondisi jalan dan tingkat kemantapan jalan yang ada adalah berturut-turut : (1) Peningkatan; (2) Pembangunan Baru; (3) Rehablitasi; (4) Perawatan; (5) Penunjangan. Hal 
ini berarti sejalan dengan analisis pada Sub Bab 5.3 tentang Analisis Kondisi jalan dimana umumnya direkomendasikan jenis pemeliharaannya adalah Peningkatan.

Setelah alternatif pemeliharaan jalan ditentukan selanjutnya dilakukan pengujian RAP. Pengujian RAP merupakan bagian penting dalam menentukan kelaikan perkerasan struktur jalan yang akan didaur ulang. Untuk dilakukan pengambilan sampel perkerasan lama pada ruas jalan yang diajukan dalam penelitian terdahulu., yaitu ruas jalan Kupang Tablolong, Ruas Jalan Soe - Kapan (Fatumnasi) di TTS, Ruas Jalan Kefamenanu (Maubesi) - Wini di TTU dan Ruas Jalan Lakafehan - Kolam Susuk di Atambua. Sampel diambil pada setiap 100 meter sepanjang 1000 meter pada bagian ruas jalan yang mengalami kerusakan.

Selanjutnya dilakukan pengujian ekstraksi, yaitu pemisahan dua atau lebih bahan dengan cara menambah pelarut yang dapat melarutkan salah satu bahan yang ada dalam campuran. Pengujian Ekstraksi dilakukan terhadap reclaimed aspal untuk memisahkan aspal dan agregat, dengan menggunakan alat Ekstrasi Tabung Refluks Gelas. Bahan yang digunakan dalam pengujian adalah bensin, cairan triklorosan dan RAP. Pengujian ini bertujuan untuk mengetahui kadar aspal dan gradasi agregat RAP sehingga dapat dilakukan penyusunan komposisi bahan sesuai perencanaan dan selanjutnya dapat dilakukan pengujian sifat aspal pada pelaksanaan dan masa pelayanannya.

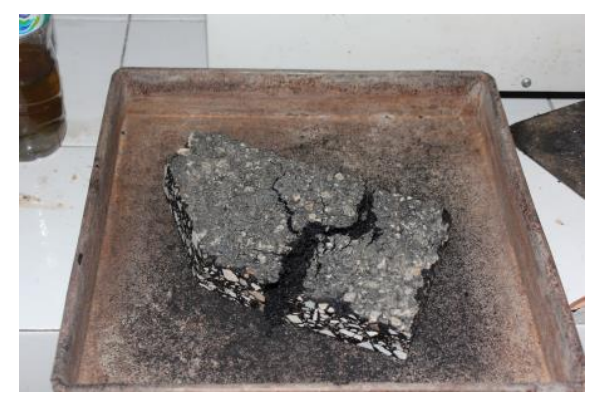

Gambar 3a. Hasil Cutting Ruas Jalan

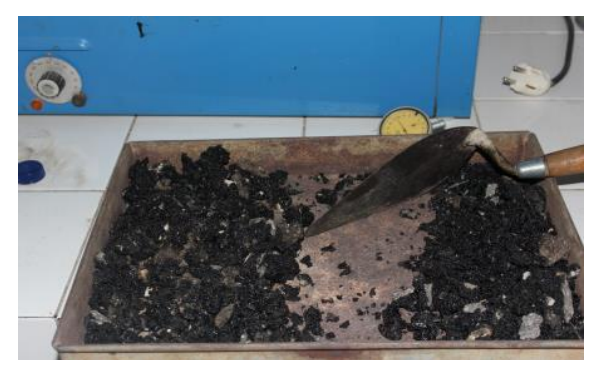

Gambar 3b. Bahan RAP

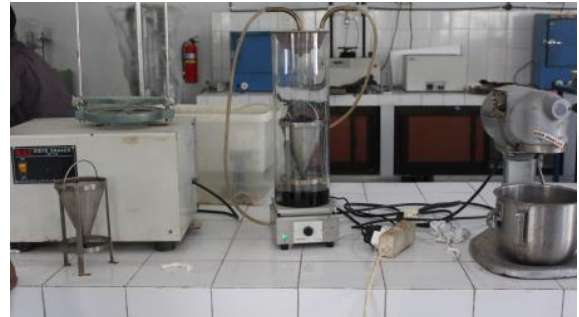

Gambar 3c. Pengujian Ekstraksi

Hasil Uji Ekstraksi dapat dilihat dari grafik 1 berikut ini:

Grafik 1. Hasil uji ekstraksi

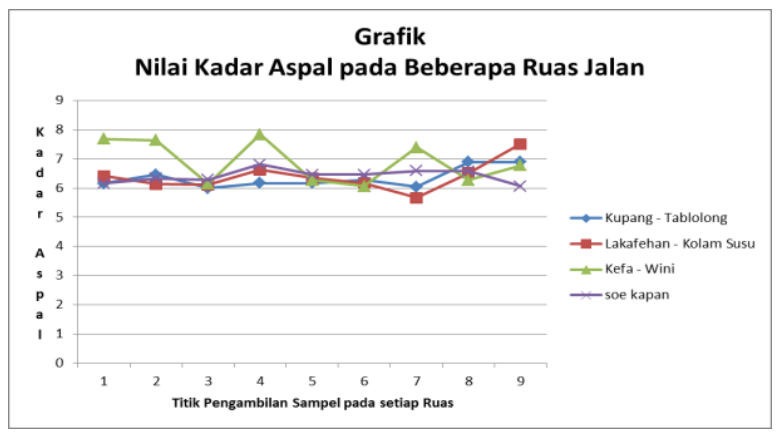

Sumber : Hasil Olah Data 
Tabel 4. Pengujian Analisis Saringan Agregat Halus dan Kasar SNI 03-1968-1990

\begin{tabular}{|c|c|c|c|c|c|c|}
\hline \multicolumn{7}{|c|}{ Ruas Jalan : Kefamenanu - Wini } \\
\hline & & \multirow{4}{*}{\begin{tabular}{|c|} 
Berat \\
Tertahan \\
\end{tabular}} & \multirow{4}{*}{$\begin{array}{c}\text { Berat Bahan Kering }= \\
\begin{array}{c}\text { Jumlah Berat } \\
\text { Tertahan }\end{array}\end{array}$} & \multicolumn{2}{|c|}{461,5 gram } & \\
\hline \multirow{2}{*}{\multicolumn{2}{|c|}{ Saringan }} & & & \multicolumn{2}{|c|}{ JUMLAH PERSEN } & \multirow{3}{*}{$\begin{array}{c}\text { Spesifikasi Laston } \\
(A C-W C)\end{array}$} \\
\hline & & & & Tertahan & Lewat & \\
\hline & & & & & & \\
\hline 25,4 & $(1 ")$ & & $\mathrm{O}$ & $\mathrm{O}$ & 100 & $100-100$ \\
\hline 19,1 & $\left(3 / 4^{\prime \prime}\right)$ & & $\mathrm{O}$ & 0 & 100 & $100-100$ \\
\hline 12,7 & $\left(1 / 2^{\prime \prime}\right)$ & & 20,4 & 0,00 & 100,00 & $90-100$ \\
\hline 9,52 & $\left(3 / 8^{\prime \prime}\right)$ & & 49,7 & 10,77 & 89,23 & $77-90$ \\
\hline No. & 4 & & 148,9 & 32,26 & 67,74 & $53-69$ \\
\hline No. & 8 & & 238,5 & 51,68 & 48,32 & $33-53$ \\
\hline No. & 16 & & 319,4 & 69,21 & 30,79 & $21-40$ \\
\hline No. & 30 & & 352,3 & 76,34 & 23,66 & $14-30$ \\
\hline No. & 50 & & 387,9 & 84,05 & 15,95 & $9-22$ \\
\hline No. & 100 & & 421,3 & 91,29 & 8,71 & $6-15$ \\
\hline No. & 200 & & 429,5 & 93,07 & 6,93 & $4-9$ \\
\hline \multicolumn{7}{|l|}{ Pan } \\
\hline \multicolumn{7}{|c|}{ Ruas Jalan : Soe - Kapan (Fatumnasi) } \\
\hline & & & Berat Bahan Kering $=$ & \multirow{2}{*}{\multicolumn{2}{|c|}{$\begin{array}{c}\text { 485, } 2 \text { gram } \\
\text { JUMLAH PERSEN }\end{array}$}} & \\
\hline \multirow{2}{*}{\multicolumn{2}{|c|}{ Saringan }} & Berat & Jumlah Berat & & & \\
\hline & & Tertahan & Tertahan & \begin{tabular}{|l|} 
Tertahan \\
\end{tabular} & Lewat & Spesifikasi Laston \\
\hline & & & & & & $(\mathrm{AC}-\mathrm{WC})$ \\
\hline 25,4 & $(1 ")$ & & $\mathrm{O}$ & 0 & 100 & $100-100$ \\
\hline 19,1 & $(3 / 4 ")$ & & $\mathrm{O}$ & 0 & 100 & $100-100$ \\
\hline 12,7 & $\left(1 / 2^{\prime \prime}\right)$ & & 21,4 & 0,00 & 100,00 & $90-100$ \\
\hline 9,52 & $\left(3 / 8^{\prime \prime}\right)$ & & 46,7 & 9,62 & 90,38 & $77-90$ \\
\hline No. & 4 & & 140,9 & 29,04 & 70,96 & $53-69$ \\
\hline No. & 8 & & 218,8 & 45,09 & 54,91 & $33-53$ \\
\hline No. & 16 & & 329,8 & 67,97 & 32,03 & $21-40$ \\
\hline No. & 30 & & 362,3 & 74,67 & 25,33 & $14-30$ \\
\hline No. & 50 & & 387,9 & 79,95 & 20,05 & $9-22$ \\
\hline No. & 100 & & 431,3 & 88,89 & 11,11 & $6-15$ \\
\hline No. & 200 & & 451,5 & 93,05 & 6,95 & $4-9$ \\
\hline Pan & & & & & & \\
\hline Ruas Jal & Kupang & Tablolong & & & & \\
\hline & & & Berat Bahan Kering $=$ & & gram & \\
\hline & & Berat & Jumlah Berat & JUM & H PERSEN & \\
\hline & $\operatorname{ran}$ & Tertahan & Tertahan & Tertahan & Lewat & Spesifikasi Laston \\
\hline & & & & & & $(\mathrm{AC}-\mathrm{WC})$ \\
\hline 25,4 & (1") & & $\mathrm{O}$ & $\mathrm{O}$ & 100 & $100-100$ \\
\hline 19,1 & $(3 / 4 ")$ & & $\mathrm{O}$ & $\mathrm{O}$ & 100 & $100-100$ \\
\hline 12,7 & $\left(1 / 2^{\prime \prime}\right)$ & & 19,3 & 4,00 & 96,00 & $90-100$ \\
\hline 9,52 & $\left(3 / 8^{\prime \prime}\right)$ & & 50,6 & 10,40 & 89,60 & $77-90$ \\
\hline No. & 4 & & 159,4 & 32,80 & 67,20 & $53-69$ \\
\hline No. & 8 & & 246,2 & 50,70 & 49,30 & $33-53$ \\
\hline No. & 16 & & 317,4 & 65,30 & 34,70 & $21-40$ \\
\hline No. & 30 & & 351,6 & 72,30 & 27,70 & $14-30$ \\
\hline No. & 50 & & 388,6 & 80,00 & 20,00 & $9-22$ \\
\hline No. & 100 & & 420,6 & 86,40 & 13,60 & $6-15$ \\
\hline No. & 200 & & 442,3 & 91,00 & 9,00 & $4-9$ \\
\hline Pan & & & & & & \\
\hline & & & & & & \\
\hline Ruas Jal & Lakafe & an Kolam S & usu & & & \\
\hline & & & Berat Bahan Kering $=$ & & gram & \\
\hline & ran & Berat & Jumlah Berat & JUM & H PERSEN & \\
\hline & & Tertahan & Tertahan & Tertahan & Lewat & Spesifikasi Laston \\
\hline & & & & & & $(\mathrm{AC}-\mathrm{WC})$ \\
\hline 25,4 & (1") & & $\mathrm{O}$ & $\mathrm{O}$ & 100 & $100-100$ \\
\hline 19,1 & $\left(3 / 4^{\prime \prime}\right)$ & & $\mathrm{O}$ & $\mathrm{O}$ & 100 & $100-100$ \\
\hline 12,7 & $\left(1 / 2^{\prime \prime}\right)$ & & 19,3 & 4,15 & 95,85 & $90-100$ \\
\hline 9,52 & $\left(3 / 8^{\prime \prime}\right)$ & & 52,7 & 11,32 & 88,68 & $77-90$ \\
\hline No. & 4 & & 158,3 & 34,01 & 65,99 & $53-69$ \\
\hline No. & 8 & & 248,4 & 53,36 & 46,64 & $33-53$ \\
\hline No. & 16 & & 320,2 & 68,79 & 31,21 & $21-40$ \\
\hline No. & 30 & & 362,3 & 77,83 & 22,17 & $14-30$ \\
\hline No. & 50 & & 377,9 & 81,18 & 18,82 & $9-22$ \\
\hline No. & 100 & & 411,3 & 88,36 & 11,64 & $6-15$ \\
\hline No. & 200 & & 439,5 & 94,41 & 5,59 & $4-9$ \\
\hline Pan & & & & & & \\
\hline
\end{tabular}

Sumber : Hasil Analisis Laboratorium 
Dari hasil pengujian kadar aspal dan agregat halus dan kasar, terlihat bahwa semua ruas jalan yang diteliti menggunakan jenis campuran Aspal Panas (Laston) atau AC (Asphalt Concrete).

Laston adalah suatu lapis permukaan yang terdiri dari campuran aspal keras dan agregat yang yang bergradasi menerus, dicampur, dihamparkan, dan dipadatkan dalam kondisi panas dan suhu tertentu. Laston bersifat kedap air, mempunyai nilai struktural, awet, dengan kadar aspal berkisar $4-7 \%$ terhadap berat campuran dan dapat digunakan untuk lalu lintas ringan, sedang, sampai berat.

Campuran ini memiliki tingkat kekakuan yang tinggi sehingga cocok diletakkan pada campuran fleksibel seperti lapis penetrasi (Hardiyatmo, 2007).

Dengan demikian maka campuran aspal pada perkerasan lama dari Ruas Jalan Kupang Tablolong, Lakafehan - Kolam Susuk, Ruas Kefamenanu - Wini, dan Ruas Soe - Kapan dapat digunakan kembali (daur ulang) untuk memperbaiki kondisi jalan yang mengalami kerusakan menggunakan jenis pemeliharaan berupa peningkatan sebagaimana yang direkomendasikan di atas.

Hal ini didukung dengan hasil pengujian Marshall, yang menunjukkan kesesuaian dengan persyaratan/spesifikasi. Hasilnya dapat dilihat pada lampiran dan resume uji Marshall dapat dilihat pada Tabel 5 dan Grafik 2 - 5 .

Tabel 5. Nilai parameter Marshall terhadap Standar BM 1998

\begin{tabular}{|c|l|c|c|c|c|}
\hline \multirow{2}{*}{ NO } & \multicolumn{2}{|c|}{$\begin{array}{c}\text { Persyaratan } \\
\text { Campuran }\end{array}$} & \multicolumn{4}{|c|}{ Ruas Jalan } \\
\cline { 3 - 6 } & & \multicolumn{1}{|c|}{$\mathbf{1}$} & $\mathbf{2}$ & $\mathbf{3}$ & $\mathbf{4}$ \\
\hline 1 & $\begin{array}{l}\text { Stabilitas, Standar BM } \\
1998 \geq 800\end{array}$ & 1744 & 1861,8 & 1956,1 & 1947,2 \\
\hline 2 & $\begin{array}{l}\text { Kelelehan (mm) } \\
\text { Standar BM } \geq 2\end{array}$ & 4 & 3,7 & 3,7 & 3,7 \\
\hline 3 & $\begin{array}{l}\text { Hasil Bagi Marshall, } \\
\text { Standar BM 200 - 500 }\end{array}$ & 463,1 & 510,3 & 532,7 & 506,1 \\
\hline 4 & $\begin{array}{l}\text { Rongga dalam Agregat, } \\
\text { Standar BM } \geq 16\end{array}$ & 16,05 & 16,23 & 16,45 & 17,22 \\
\hline 5 & $\begin{array}{l}\text { Rongga terisi Aspal, } \\
\text { Standar BM } \geq 65\end{array}$ & 66,23 & 72,49 & 78,41 & 81 \\
\hline 7 & $\begin{array}{l}\text { Rongga dahm } \\
\text { Campura, Stamdar BM }\end{array}$ & 5,42 & 4,47 & 3,55 & 3,27 \\
\hline 7 & $\begin{array}{l}\text { Index peredaman, } \\
\text { Standar BM } \geq 75\end{array}$ & 66,23 & 72,49 & 78,41 & 81 \\
\hline
\end{tabular}

Grafik 2. Perbandingan nilai kadar aspal dan kepadatan

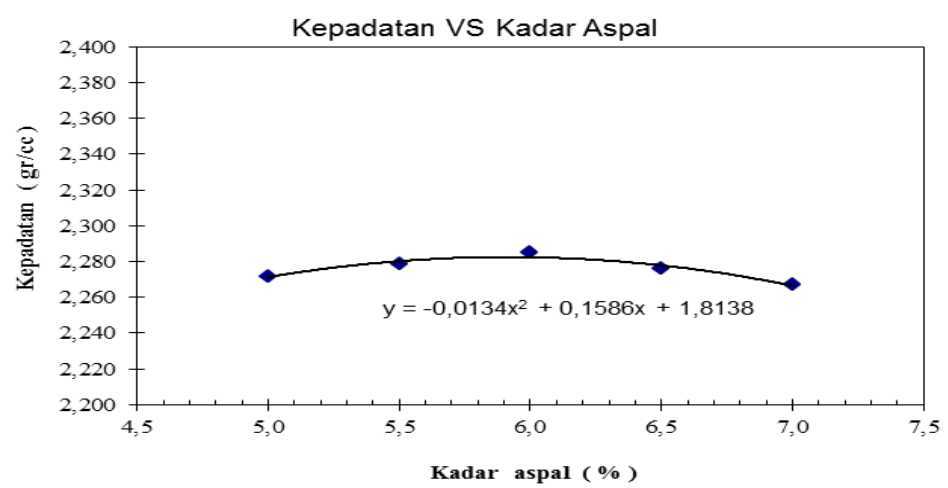

Grafik 3. Perbandingan nilai kadar aspal dan VMA

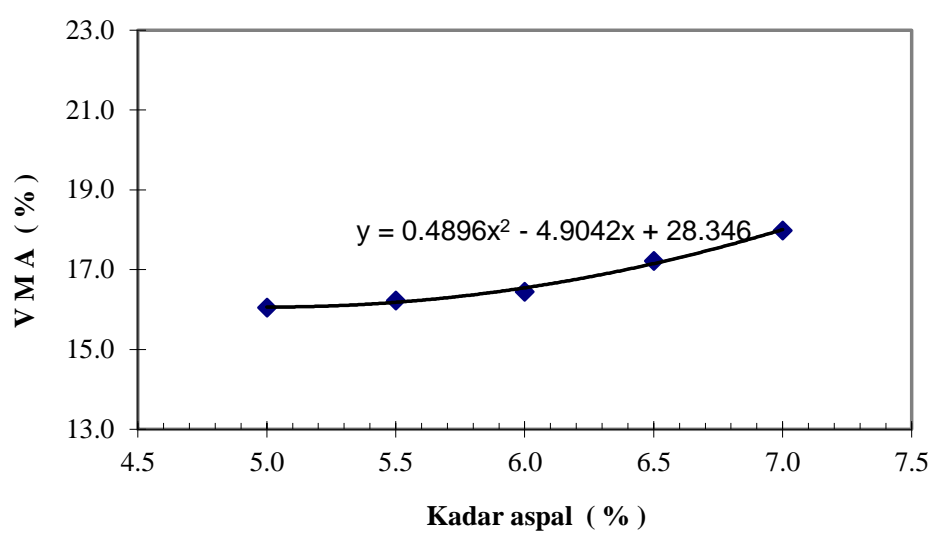

Grafik 4. Perbandingan nilai kadar aspal dan VFB

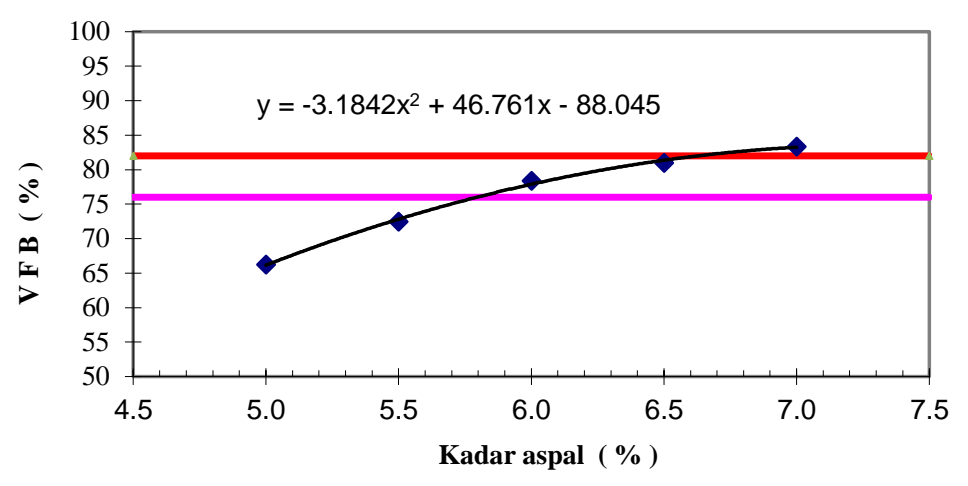


Grafik 5. Perbandingan nilai kadar aspal dan VIM

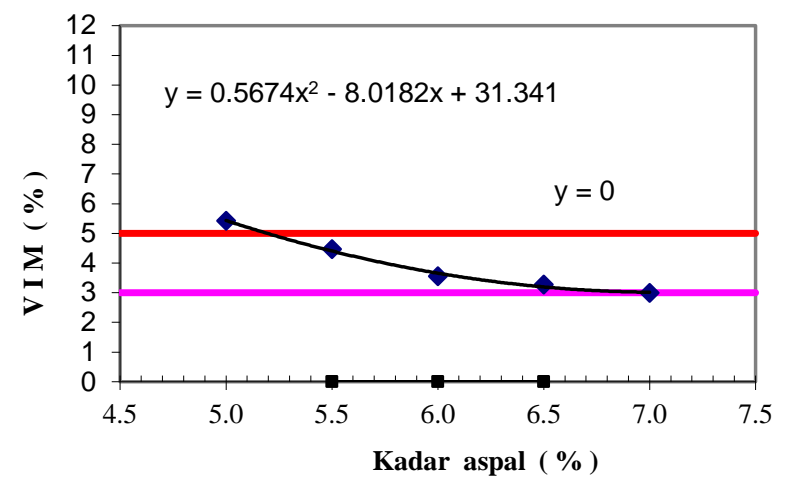

Grafik 6. Perbandingan nilai kadar aspal dan Stabilitas

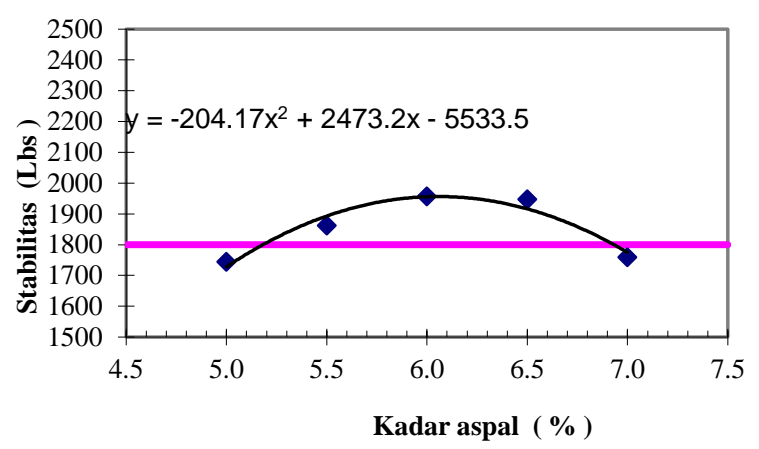

Grafik 7. Perbandingan nilai kadar aspal dan Kelelahan

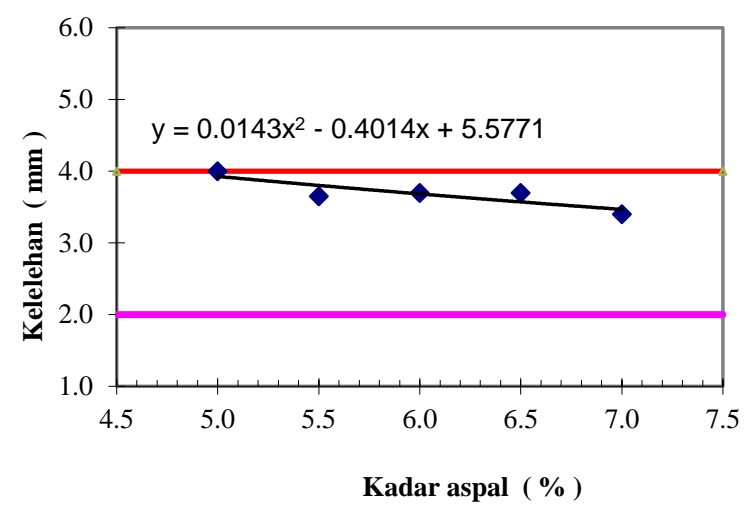

Dari hasil tersebut di atas maka dapat disimpulkan bahwa sebagian besar campuran perkerasan lama masih dapat memenuhi standar parameter Marshall yang harus terpenuhi berdasarkan Metode Bina Marga Tahun 1998.

Dengan demikian, maka penggunaan kembali material eksisiting sebagai bahan untuk melakukan pemeliharaan jalan pada ruas jalan yang ditinjau, dapat digunakan. Untuk itu, selanjutnya perlu dilakukan analisa terhadap nilai ekonomi dari penggunaan material perkerasan lama. Langkah pertama yang perlu dilakukan adalah menghitung besarnya biaya satuan pekerjaan per meter persegi. Menurut cara menghitung biaya satuan pekerjaan berdasarkan pada kebutuhan tenaga kerja, peralatan dan bahan. Contoh analisa biaya tertera pada Tabel 6 berikut ini.

Tabel 6. Analisa Perhitungan Biaya Pekerjaan Jalan Khusus Lapisan AC Berdasarkan AHSP Bidang Pekerjaan Umum Tahun 2013

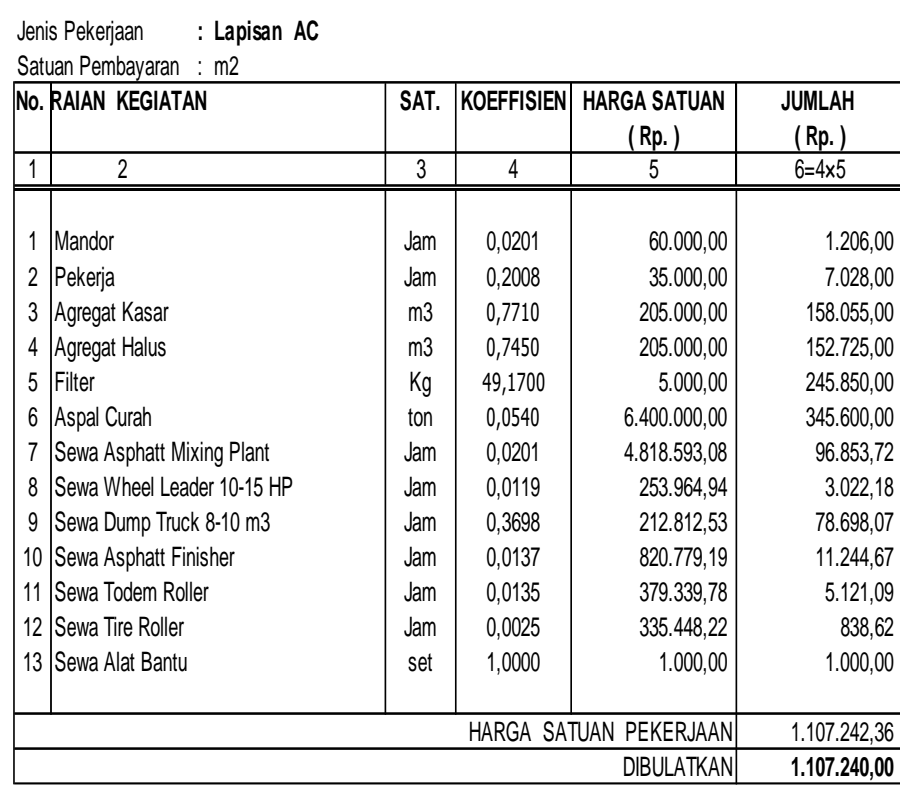

Sumber : Hasil Olah Data, AHSP Bidang PU, 2013

Berdasarkan hasil pengujian terhadap kadar aspal dan agregat diketahui bahwa pada ke empat ruas jalan yang diteliti, kadar aspal dan agregat masih layak untuk digunakan kembali. Dengan demikian Analisa tersebut di atas dapat dimodifikasi dengan menghilangkan material/agregat, filler dan Aspal sehingga dapat diperoleh harga baru dan dapat dihitung rasio penghematan biaya menurut asumsi tersebut di atas adalah sebesar 19\% setiap tonnya atau sebesar Rp. 210.540,00 (Lihat Tabel 7). Namun demikian, dalam beberapa kali pengujian terlihat pada ruas-ruas tertentu perlu ditambahkan kadar 
aspal atau zat tambah sebesar $10-15 \%$ dari total asphal yang dibutuhkan, sehingga jika dipakai pendekatan penambahan material baru sebesar $10 \%$ maka terdapat penghematan sekitar $13 \%$ atau sekitar Rp. 144.900,00. (dapat dilihat pada Tabel 8.).

Tabel 7. Analisa Perhitungan Biaya Pekerjaan Jalan Khusus Lapisan AC Berdasarkan AHSP Bidang Pekerjaan Umum Tahun 2013 yang dimodofikasi (tanpa bahan tambah)

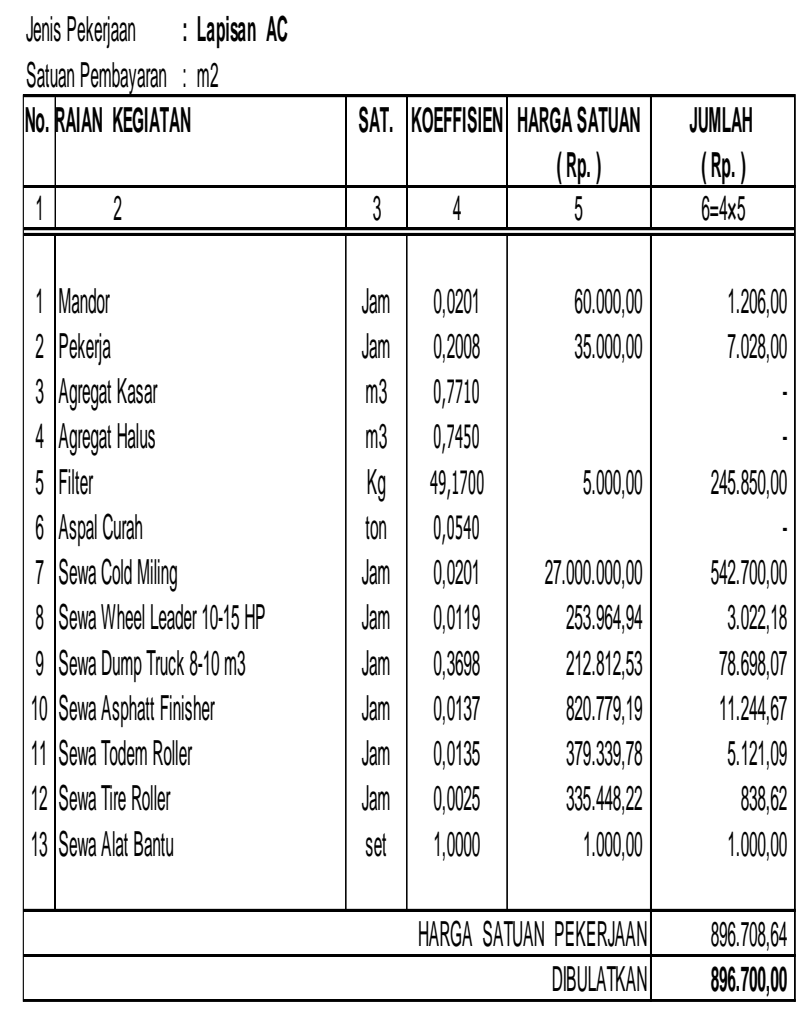

Tabel 8. Analisa Perhitungan Biaya Pekerjaan Jalan Khusus Lapisan AC Berdasarkan AHSP Bidang Pekerjaan Umum Tahun 2013 yang dimodifikasi (dengan bahan tambah).

\begin{tabular}{|c|c|c|c|c|c|}
\hline \multicolumn{2}{|c|}{$\begin{array}{ll}\text { Jenis Pekerjaan } & \text { : Lapisan AC } \\
\text { Satuan Pembayaran } & : \mathrm{m} 2\end{array}$} & \multirow{3}{*}{$\begin{array}{c}\text { SAT. } \\
3 \\
\end{array}$} & \multirow{3}{*}{\begin{tabular}{|c|} 
KOEFFISIEN \\
4 \\
\end{tabular}} & \multirow{2}{*}{$\begin{array}{l}\text { HARGA SATUAN } \\
(\mathrm{Rp} .)\end{array}$} & \multirow{2}{*}{$\begin{array}{l}\text { JUMLAH } \\
\text { (Rp.) }\end{array}$} \\
\hline \multicolumn{2}{|c|}{ No. RAIAN KEGIATAN } & & & & \\
\hline \begin{tabular}{|l|}
1 \\
\end{tabular} & 2 & & & 5 & $6=4 \times 5$ \\
\hline 1 & Mandor & Jam & 0,0201 & $60,000,00$ & $1.206,00$ \\
\hline 2 & Pekerja & Jam & 0,2008 & $35.000,00$ & $7.028,00$ \\
\hline 3 & Agregat Kasar & m3 & 0,7710 & $20.500,00$ & $15.805,50$ \\
\hline 4 & Agregat Halus & m3 & 0,7450 & $20.500,00$ & $15.272,50$ \\
\hline 5 & Filter & $\mathrm{Kg}$ & 49,1700 & $5.000,00$ & $245.850,00$ \\
\hline 6 & Aspal Curah & ton & 0,0540 & $640.000,00$ & $34.560,00$ \\
\hline 7 & Sewa Cold Miling & Jam & 0,0201 & $27.000 .000,00$ & $542.700,00$ \\
\hline 8 & Sewa Wheel Leader 10-15 HP & Jam & 0,0119 & $253.964,94$ & $3.022,18$ \\
\hline 9 & Sewa Dump Truck 8-10 m3 & Jam & 0,3698 & $212.812,53$ & $78.698,07$ \\
\hline 10 & Sewa Asphatt Finisher & Jam & 0,0137 & $820.779,19$ & $11.244,67$ \\
\hline 11 & Sewa Todem Roller & Jam & 0,0135 & $379.339,78$ & $5.121,09$ \\
\hline 12 & Sewa Tire Roller & Jam & 0,0025 & $335.448,22$ & 838,62 \\
\hline 13 & Sewa Alat Bantu & set & 1,0000 & $1.000,00$ & $1.000,00$ \\
\hline \multicolumn{5}{|c|}{ HARGA SATUAN PEKERJAAN } & $962.346,64$ \\
\hline & & & & DIBULATKAN & $962.340,00$ \\
\hline
\end{tabular}

Dengan demikian maka ditinjau dari biaya terdapat penghematan sebesar $13-19 \%$ per ton dibandingkan dengan menggunakan teknologi konvensional. Oleh karena itu, pada keempat ruas jalan tersebut sangat tepat jika menggunakan teknologi daur ulang perkerasan jalan dengan terlebih dahulu melakukan pengujian terhadap material lama.

\section{KESIMPULAN}

Dari berbagai pengujian terhadap kadar aspal, agregat halus dan kasar dari perkerasan jalan Ruas Kupang - Tablolong, Lakafehan - Kolam Susu, Kefamenanu - Wini dan Soe - Kapan (Fatumnasi) dan analisa biaya pekerjaan jalan maka dapat disimpulkan bahwa :

1. Ruas jalan yang mengalami rusak berat adalah ruas Kupang - Tablolong dari Gapura menuju panati, dan ruas Kapan - Fatumasi. Nilai RCI dari ruas-ruas jalan tersebut adalah 2 - 3. Kategori rusak ringan dialami oleh ruas jalan Soe - Kapan dengan nilai RCI adalah 6. Selanjutnya kerusakan kategori sedang, dialami oleh jalan ruas Batulesa Tablolong dan Kefamenanu - Wini dengan 
nilai RCI adalah 7. Ruas jalan terakhir adalah ruas Lakafehan - Kolam Susuk kondisi baik dengan nulai RCI adalah 8.

2. Rekomendasi penanganan yang dapat dilakukan adalah dengan peningkatan untuk ruas jalan dengan kondisi rusak ringan rusak berat, dan pembangunan baru pada ruas yang mengalami rusak berat. Sedangkan ruas jalan dengan kondisi sedang dapat dilaksanakan rehabilitasi dan jika kerusakan belum parah dapat dilakukan perawatan rutin

3. Jenis campuran beraspal pada perkerasan Ruas Jalan Kupang - Tablolong, Lakafehan Kolam Susu, Kefamenanu - Wini dan Soe Kapan (Fatumnasi) adalah Jenis Campuran Lapis Aspal Beton atau Asphalt Concrete (AC)

4. Rata-rata kadar aspal dalam campuran perkerasan aspal lama adalah antara 6\% $7,8 \%$, yang menunjukkan masih dalam batas toleransi untuk jenis campuran Laston (AC) dimana disyaratkan $(4-7 \%$ terhadap berat campuran).

5. Analisa biaya pekerjaan berdasarkan AHSP Bidang PU 2013, terdapat penghematan sebesar $13-19 \%$ biaya per ton pekerjaan Jalan AC.

\section{DAFTAR PUSTAKA}

Aly, Mohamad Anas, 2007, Teknik Dasar dan Potensi Daur Ulang Konstruksi Jalan, Yayasan Pengembang Teknologi dan Manajemen, Jakarta

Bria, Melchior, dkk, 2015, Penentuan Nilai Kondisi dan Program Pemeliharaan Ruas Jalan menuju Lokasi Wisata Andalan di Timor, Jurnal Inersia Vol. VII No. 2, September 2015

Departemen Pekerjaan Umum, 1976, Manual Pemeriksaan Jalan, Direktorak Jenderal Bina Marga Departemen Bahan Jalan

Departemen Pekerjaan Umum, 1999, Pedoman Perencanaan Campuran Beraspal Panas dengan Pendekatan Kepadatan Mutlak

Departemen Pekerjaan Umum, 1983, Petunjuk Pelaksanaan Lapis Tipis Aspal Beton (Flexible Lataston),
Penelitian dan Pengembangan Prasarana Transportasi)

Departemen Pekerjaan Umum, 2006, Modul Perencanaan Campuran Beraspal Panas (Badan Penelitian dan Pengembangan, Puslitbang Jalan dan Jembatan)

Filter, Ari, 2008, Kuat Tarik dan Kuat Tekan dari Hot Rolled Asphalt (HRA) diukur pada suhu terkontrol. Program Studi Teknik Sipil, Program Sarjana Universitas Sebelas Maret Surakarta

Fuad, Yusuf, 2008, MakalahPavement Recycling, (Direktur PT. Conbloc Infratecno)

Hardiyatmo, Hary Christady, 2007, Pemeliharaan Jalan Raya, Gajah Mada University Press

Nicholls J.C, 1998, Asphalt Surfacing (Aguide to Asphalt Surfacings and Treatment Used for the Surface Course of Road Pavements)

SNI 03-2417-1996, Cara uji keausan agregat dengan mesin abrasi Los Angeles

SNI 03-1737-1989, Pelaksanaan Lapis Campuran Beraspal Panas, Badan Litbang Dept. PU

Soemino, dkk, 2006, Pemeliharaan Jalan, Bahan Kuliah Prog. Magister Manajemen Aset, FTSP - Institut Teknologi Spuluh Nopember Surabaya

Sukirman, Silvia, 1995, Perkerasan Lentur Jalan Raya, Penerbit Nova Bandung

Sudarssono, D.U,1993, Rencana Campuran (Mix Design), Yayasan Badan Penerbit Pekerjaan Umum Jakarta

Tm, Suprapto, 2004, Bahan dan Struktur Jalan Raya, Biro Penerbit Teknik Sipil Universitas Gajah Mada

Sudarssono, D.U,1993, Rencana Campuran (Mix Design), Yayasan Badan Penerbit Pekerjaan Umum Jakarta

Wignal, Arthur, 2003, Proyek Jalan, Teori dan Praktek, Penerbit Erlangga Jakarta

Departemen Pekerjaan Umum, 2005, Teknik Bahan Perkerasan Jalan, (Badan 